\title{
ROMAN BRIDGES ON THE LOWER PART OF THE DANUBE
}

Isabella Floroni

Andreia-Iulia Juravle

UDK: 904:624.21"652"

DOI: 10.14415/konferencijaGFS2019.015

Summary: The purpose of the paper is to present the Roman bridges built across the Romanian natural border, the Danube, during the Roman Empire expansion. Some of these are less known than the famous Traian's bridge in Drobeta Turnu Severin. The construction of bridges on the lower part of the Danube showed the importance of conquering and administrating the ancient province of Dacia. The remaining evidences prove the technical solutions used by the Roman architects at a time when public works had developed.

Keywords: Danube bridges, pontoon bridge, Bridge of Constantine the Great, Columna Traiana

\section{INTRODUCTION}

The Danube ${ }^{1}$ was once a long-standing frontier of the Roman Empire, and today flows through 10 countries, more than any other river in the world. Originating in Germany, the Danube flows southeast for 2,850 km, passing through or bordering Austria, Slovakia, Hungary, Croatia, Serbia, Romania, Bulgaria, Moldova and Ukraine before draining into the Black Sea.

Romania has the longest access to the river, around $1075 \mathrm{~km}$, of which $225 \mathrm{~km}$ on Romanian territory exclusively. 
Савремена достигнућа у грађевинарству 23-24. април 2019. Суботица, СРБИЈА

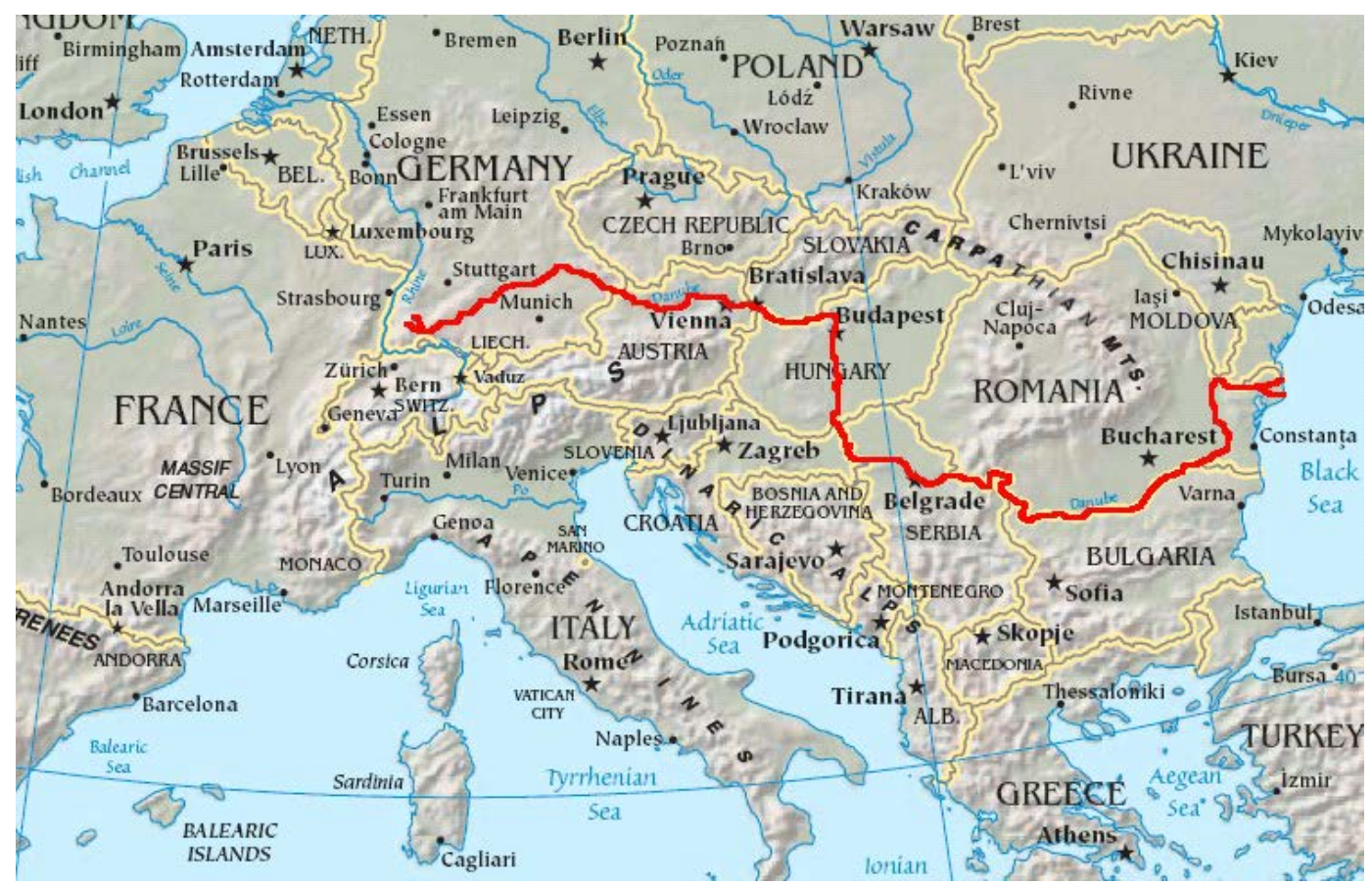

Fig. 1 Map of the main course of the Danube

During the Roman Empire many wooden or masonry bridges were built, some of which lasted longer, other designed for ephemeral military expeditions. The most numerous and important were made on the lower course of the river, from the Iron Gates to the Black Sea.

In their list they are presented in topographical order:

-Traian's double pontoon bridge from Lederata and Dierna (101 A.D.)

-Traian's stone bridge from Tr. Severin (103-105 A.D.)

-Cornelius Fuscus pontoon bridge at Vadin-Orlea (86/87 A.D.)

-the stone bridge of Constantine the Great from Oescus-Sucidava (328 A.D.)

-the bridge of M. Laberius Maximus (102 A.D.)

-the pontoon bridges of Valens

Out of the enlisted bridges, five are related to the battles between the Romans and the Dacians in the reign of Dominitian and Trajan. The other three rose in the 4th century, one with the aim of linking the empire to the territories conquered by Constantine the Great in the north of the Danube, and the other two with the purpose of passing the Roman troops north of the river.

The presence of such a high number of bridges in this region proves the military and economic importance of Dacia and its eastern regions between the first and fourth century. Since the Renaissance, some Roman bridges, like Trajan's and Constantine the Great's, have enjoyed a great deal of attention from some scholars or curious people to discover the secrets of the ancient technique. The interest of the scientific world for these monuments has always been stimulated by the desire to know the methods used by the 
Contemporary achievements in civil engineering 23-24. April 2019. Subotica, SERBIA

Romanian technique regarding the foundation of the bridge's feet in the deep and fast water of the Danube.

From time to time, these bridges have enjoyed some fine archeological research, made on site, followed by the publication of some historical and archeological monographs.

\section{CORNELIUS FUSCUS’ PONTOON BRIDGE FROM VADIN-ORLEA}

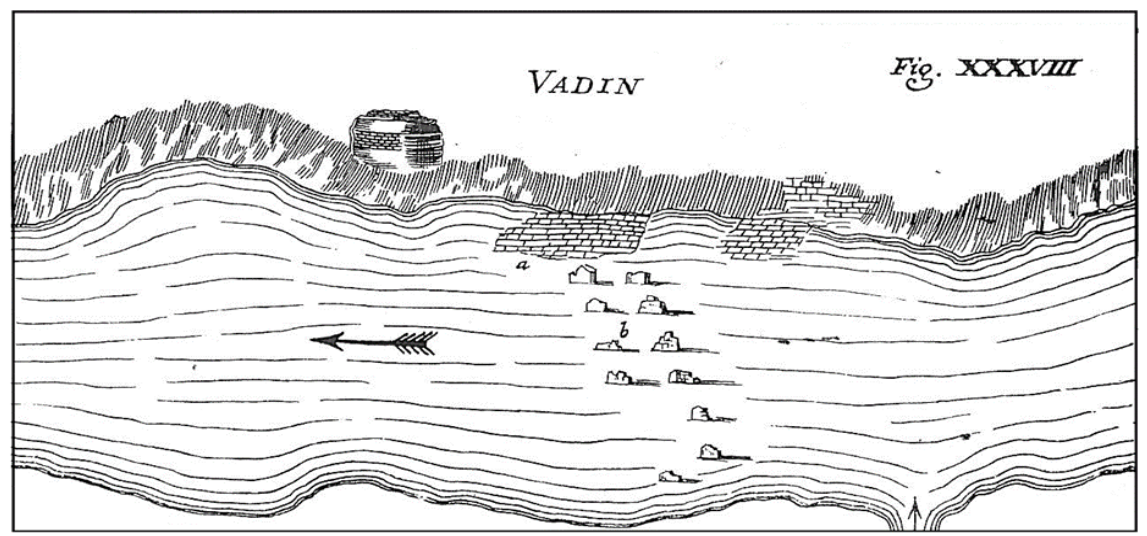

Fig.2 .The ruins of the roman bridge in Vadin-Orlea (after Marsigli 1691)

Marsigli was convinced that he had discovered in Vadin the remains of the bridge built by Constantine the Great in 328 A.D., a monument that holds an interesting monographic chapter in his work. In reality, the true bridge of Constantine the Great is located $16 \mathrm{~km}$ below Vadin, between Oescus and Sucidava, and has been well-defined by modern research.

The bridge has strong pillars on two rows in the river bed, probably following the same ingenious technique applied by Caesar on the Rhine. At Vadin-Orlea the bridge's feet stretched over a length of about 1,000-1100 $\mathrm{m}$ in a place where the Danube's ditch reaches 6-7 m depth. Taking advantage of a drop in water levels during the summer, the Romans could beat these pillars in the Danube bed, with strong rams fixed on ships and handled by pulleys.

The presence of masonry platforms at its ends was imposed, as it is today, for a good connection with the shoreline. But the wooden bridge between Vadin and Orlea did not have the strength and strategic role of the stone bridges of Tr. Severin and Celei. By his departure and his topographic situation our bridge could not directly link the cities of Oescus and Sucidava. Everything indicates that we are dealing with a bridge built for a military expedition, in a place that offers advantageous opportunities for a quick construction and in summer time. Being built at a small height, it could easily be touched by the floods of the river, and in the winter it was broken by the ice sheets. It is more than sure that it does not have wooden vaults and no single floor joining the pillars directly into the Danube bed. These pillars had been swathed vertically into the river bed, not oblique and two by two in the technique of self-supporting bridges. The pillars were used to anchor vessels over which the floor of the bridge was then covered. 
Савремена достигнућа у грађевинарству 23-24. април 2019. Суботица, СРБИЈА

Historical sources tell that, the year of the construction is the same with Cornelius Fuscus' failed expedition in Dacia in 87 A.D. After Fuscus's failure and the withdrawal of his army's remnants across the Danube, the bridge was immediately dismantled to prevent Decebal's eventual naval over the river.

\section{TRAIAN'S PONTOON BRIDGES FROM THE YEAR 101 A.D.}

In the field of the construction of the Danube bridges, the conqueror of Dacia appears well-known through the famous bridge of Apollodor Damascus. As far as his pontoon bridges spread on the Banat Danube, in 101 BC, they are more known by those who have dealt with the interpretation of the sculptures of his commemorative columna in the capital of the empire.

The passage of the Danube on bridges by the Roman armies in the spring of $101 \mathrm{BC}$ is an archaeological reality confirmed by the IV-V scenes of the Trajan's Column in Rome.

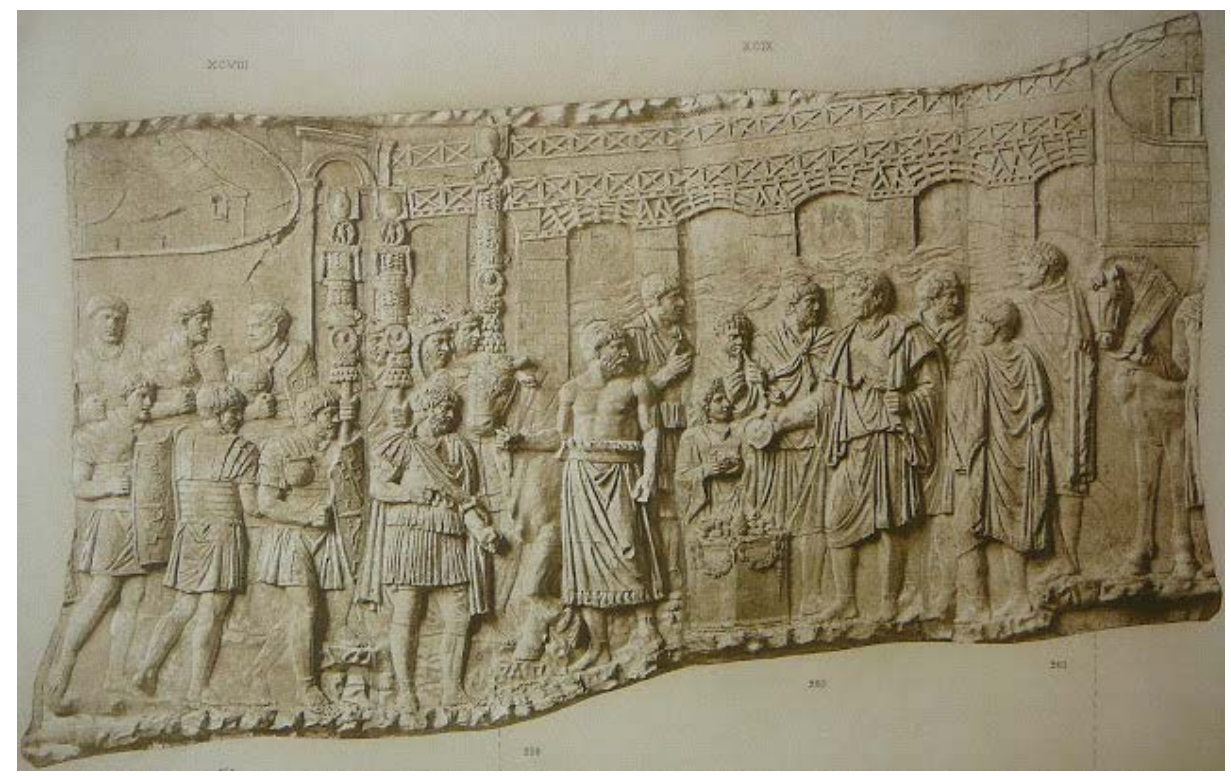

Fig. 3 Drobeta Bridge on Trajan’s Column Reconstitution

In the 4th scene, the ships in number of 6 are of the same shape and size, connected to each other with thick beams. An important topographic element that must keep our attention to this scene is the masonry arch on its left, below which the soldiers undo to step directly on the bridge, which could only be the portal of the bridge situated on the right bank of the Danube. The stone blocks are sustained by two pillars with capitals.

Unexpectedly in the fifth scene, we have a second pontoon bridge, this one is fragmentary (reduced to two vessels and connected to the shore) but worked in the same technique as the previous one. This bridge cannot be the continuation of the bridge from the fourth scene. Some specialists believed that there was only one bridge, formed out of two parts, 
Contemporary achievements in civil engineering 23-24. April 2019. Subotica, SERBIA

other researchers had another explanation. They supposed the construction of two adjacent bridges in the same place and intended for the simultaneous passage of the Roman army. Conrad Cichorus, the most assiduous reader of the column brought arguments in favor of the existence of these two different Roman bridges. It is supposed that the army, split in two, crossed the river at the same time in order to meet again further on the other side of the river, before the battle.

While the location of the first bridge is known to be the ancient Lederata (in present Ram) on the Serbian river side, the second one is thought to be difficult to appreciate. However these two locations were definitely chosen far one from the other, to avoid the unfavorable conditions encountered at the narrow passage of the Danube at "Cazane" near the Iron Gates.

\section{TRAIAN'S BRIDGE OVER THE DANUBE AT DROBETA-TURNU SEVERIN}

Traian realized that domination over Dacia province could not be achieved without building a fixed bridge across the Danube. Consequently the need of movement for military purposes and the need to administrate the newly conquered province, located on the Danube left side, imposed the construction of this bridge, between 103-105 A.D

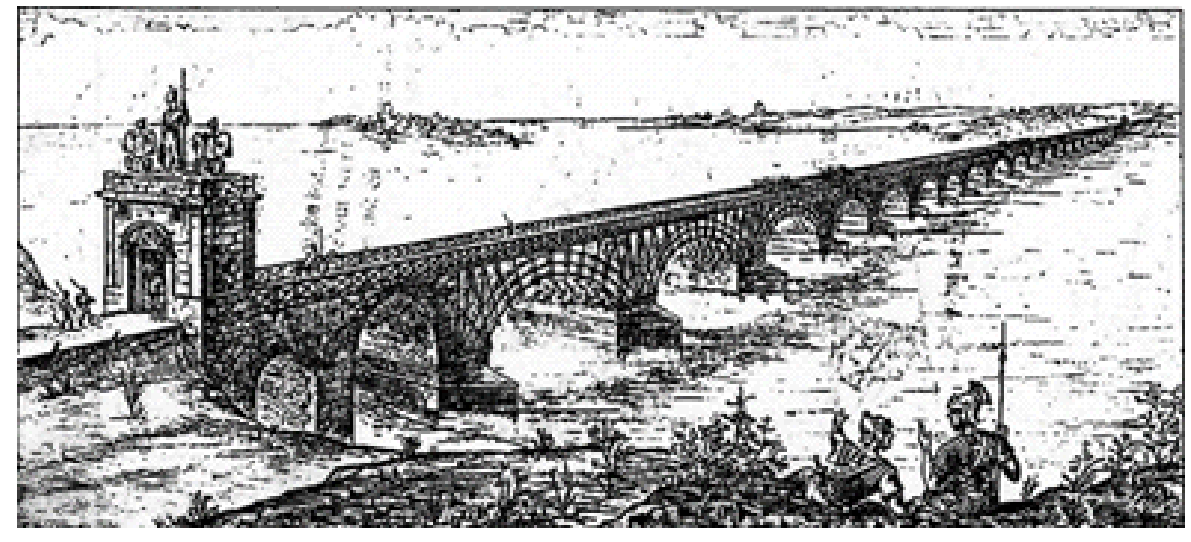

Fig. 4. Traian's bridge over the Danube in Drobeta-Turnu Severin

Modern researchers were astonished by the $1200 \mathrm{~m}$ length of the bridge and looked into the enigma of its technical building solution. The bridge was deemed superior to all the other bridges. Unfortunately, the monography of the bridge, written by Apollodor from Damascus who was the architect and builder of the bridge, had been lost.

The investigations performed in 1858 showed that the lower part of the bridge piers, differently damaged in time, were made of broken stone masonry with mortar binder. The whole structure was surrounded by a strong walls made by blocks of crushed stone. The ruined piers length varied from $21.50 \mathrm{~m}$ to $22.75 \mathrm{~m}$ and their width from $14.22 \mathrm{~m}$ to $14.85 \mathrm{~m}$. 
In 1909 the Romanian Hydraulic Service ordered the demolition of two ruined piers located close to the Romanian shore, because they obstructed the navigation along the river. When divers worked in the Danube area, they discovered traces of wooden caissons used for the construction of the piers.

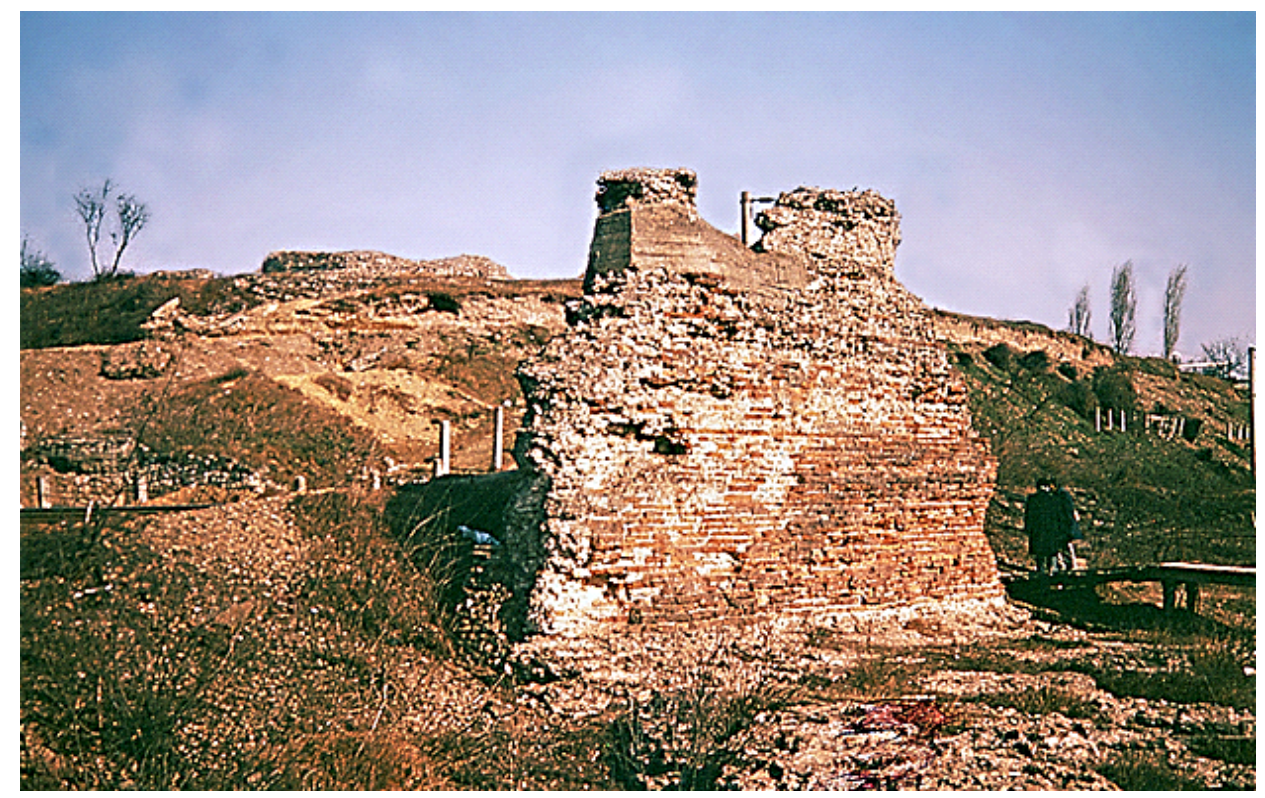

Fig. 5. Ruins of the ancient pier on the Romanian shore

The most difficult part of the construction seems to have been the foundation of the piers on the riverbed. These 20 piers were provided with front-breakwaters and downstream breakwaters of the same shape. On the exterior of the pier two rows of wooden piles were identified having a square cross section and with wooden planks inside, which would lead to the idea of a cofferdam. On the outline of this enclosure regularly wrought stone blocks were identified, in the form of a dry masonry. Inside of this masonry, blocks of Roman cement concrete were found, containing pieces of broken bricks inside as aggregates. Lattices made from oak tree trunks were used to tie together the concrete and stone blocks of the foundation, which was laid directly on the bottom of the Danube River (Fig.5).They would support the superstructure, that was made out of wooden arches (with a remarkable span of $51 \mathrm{~m}$ ). The abutments are today the best preserved elements among the ruins of the bridge thanks to their special masonry. The images shown on Traian's Column in Rome, as well as ancient coins clearly indicate a wooden structure combined with arch structural elements.

When it comes to the destruction of the bridge, there are two theories:

- After Traian's death in the year 118 the destruction of the superstructure was ordered by the emperor Hadrianus. A reason for this decision could be the barbarians that got into Dacia;

- The second view indicates that the bridge destruction was caused by the floods; we do not know the exact details. 
Contemporary achievements in civil engineering 23-24. April 2019. Subotica, SERBIA

In conclusion, the bridge over the Danube in Drobeta - Turnu Severin was one of the most important constructions of the Roman empire. It is sure that the bridge was not built only for a single military company; it was constructed for years on the purpose of strong connection with the territories over the Danube.

Even nowadays the ruins of one pier can be admired on the Romanian river side.

\section{CONSTANTINE THE GREAT'S BRIDGE FROM CELEI}

Data about the Danube bridge from the Constantine Emperor's dynasty are nowadays rather small compared to that of Tr. Severin. Its ruins are kept in a modest condition. The south part of the bridge, on the Bulgarian shore, hasn't yet been identified.

Its location is well known, between the Bulgarian village Ghighi and Celei in Romania, at that time two prosperous villages called Oescus and Sucidava. The choice of the crossing point Oescus-Sucidava was taken in accordance with the military plans of Constantine the Great. The bridge was inaugurated by Constantine the Great in 328 A.D. and it realized a permanent contact with the northern Danubian territories. Archeological discoveries and historical research conducted to the same technical solution adopted for Traian's bridge. For Romanity at the lower Danube, the Constantine Bridge had a special significance. Such a stable, costly and grandiose construction could not rise if north of the river the empire did not reign important territories.

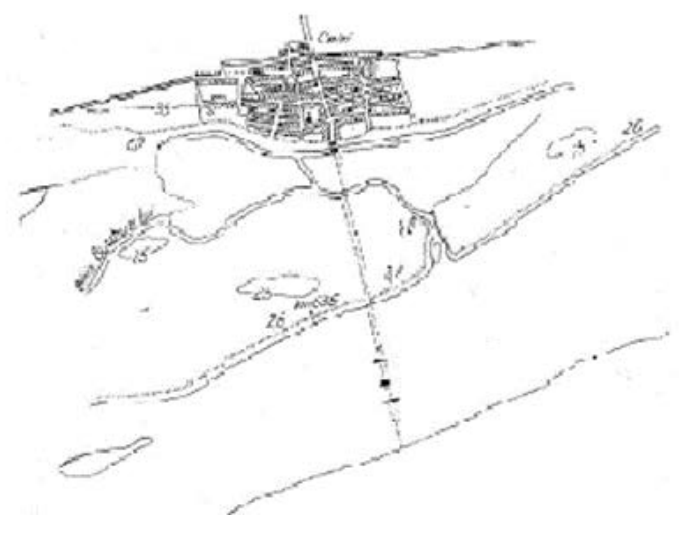

Fig.6. a) Bridge’s location 


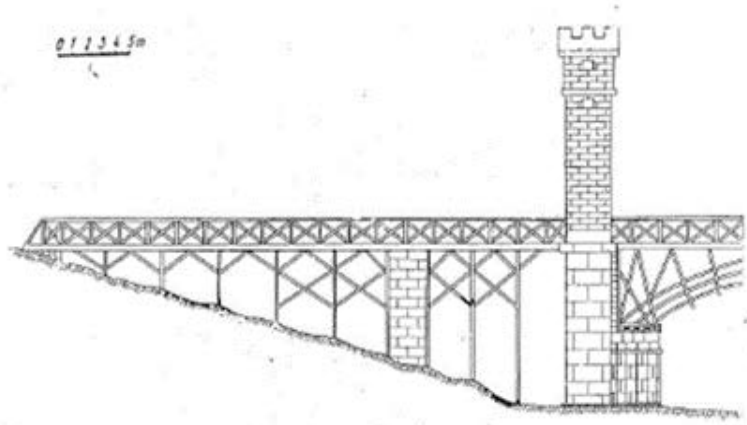

b)Final span of the bridge (reconstruction)

\section{CONCLUSIONS}

Historical and archaeological data prove that the Romans built important river bridges along the lower Danube, much more durable than in other adjacent regions of the Roman Empire. It is the sector where the empire armies were required to make great defensive efforts in the first two centuries BC against the Dacian kingdom, and after the liquidation of Roman rule in Dacia, against the migratory people.

The two grandiose stone bridges rejoiced the admiration of the ancient world and the curiosity of the modern one. Their technical enigma has formed a method of building their legs in the riverbed. It seems that the "caisson" system was applied for the first time by Apollodor.

\section{BIBLIOGRAPHY}

1. Tudor D.:Podurile romane de la Dunarea de jos("Roman Bridges over the lower Danube"Romanian Academy Publishing House,1971,Bucharest).

2. Popa N., Bancila R., Florea S : "Traian's Bridge over the Danube at Drobeta Turnu Severin”First International Conference Bridges on the Danube”, Vienna- BratislavaBudapest, September 1992.

3. Florea S.,Ionescu C.: Podul creaţie, trăire şi cunoaştere ("The bridge : creation, passion and knowledge" [Vol. 1], ISBN 978-973-88302-4-0 